\title{
On Cultural Connotations of English Idioms WANG Yan
}

\author{
School of Foreign Languages, Wuhan Business University, Wuhan, Hubei 430056 \\ wangyan1999818@163.com
}

Keywords: idiom; English idioms; culture; cultural connotations

\begin{abstract}
Idioms are widely recognized as the essence or the crystallization of language. They are closely connected and cannot be separated from culture. English idioms are formed in a particular historical period and passed from generation to generation, embedded with unique cultural connotations, such as historical development, natural environments religious belief, custom \& habits, sports \&entertainment, fables \& mythologies, literary works, etc.
\end{abstract}

\section{Introduction}

English idioms are an important part of the English vocabulary. "Idioms usually carry more impact than non-idiomatic expression because of their close identification with a particular language and culture [1]."

An idiom, according to Fernando [2], may be defined as a conventionalized, often but not always non-literal, multiword expression. Idioms reflect the environment, life, history, and culture of the native speakers, and are closely associated with their innermost spirit and feeling.

\section{Cultural Connotations of English Idioms}

2.1 The Relationship Between Idiom and Culture Language is an intrinsic part of culture. It carries culture and plays a very important role in it. Without language, culture would not be possible. On the other hand, language is influenced and shaped by culture; it reflects culture [3].

An idiom is a comparatively fixed language form in matters of meaning and structure, embedded with rich cultural connotations. Each of them, formed in a particular historical period and passed from generation to generation, reflects unique cultural elements such as natural environment, religion, custom and habits, etc. The relationship between idiom and culture is actually the one between language and culture.

2.2 Reflecting Historical Development Historical Development has great influence on language. During the long development, the traces of historical culture were left over in the idioms. Looking back historical development, national conquer and assimilation, war between different ethnicity influence culture greatly.

2.2.1 Roman Conquest Between the 8th and 5th centuries $\mathrm{BC}$, the Celts moved to Britain and became the dominant group there. Roman king Claudius invaded Britain in 43 AD and three years later conquered the country. Britain became a province of the Roman Empire. With the occupation, Roman culture dominated the high society at that time. Latin became official language and even people could not assume the office of the government if they could not speak Latin. Romans occupied Britain for 400 years. Even now it is not difficult to see the traces of Roman culture in English. Such proverbs as "do in Rome as the Romans do, Rome was not built in a day, all roads lead to Rome" are known to every family in Britain.

2.2.2 The Anglo-Saxon Invasion After the Romans left, the Angles, Saxons, and Jutes from Denmark, Northern Germany, and the coast of the North Sea landed in Britain. Since there were a lot more Angles and Saxons than Jutes, they were commonly referred to as the Anglo-Saxons. They liked the new place and refused to leave. The Britons fought bravely but they were no match for the Anglo-Saxons because they had been protected by the Romans for centuries. By the late 6th century, the conquest was remarkably thorough. From that time, English, meaning the language of the Angles, replaced the old Celtic language as the dominant language of the land. There is no modern 
English without the Anglo-Saxon invasion.

e.g. go through fire and water

The Anglo-Saxons did not have sophisticated legal system. The assumption of guilt was up to the accused to prove his innocence by submitting himself to an "ordeal". The process was known as "trial by ordeal". It was an appeal to divine judgment when the judges were not sure whether the accused person was guilty or innocent. There were several types of ordeals. One of the common forms was to throw hands of the accused into boiling water. If their hands go through fire and water, they are not hurt, and then they were innocent. The figurative meaning of the idiom is to go through many hardships.

2.2.3 The Danish Invasion In the late 8th century, the Vikings from the Scandinavian countries in Northern Europe, Norway and Denmark, came in their long boats and raided the coast of England. Later they changed the plundering into the campaign of conquest. Alfred the Great led his army to resist the Vikings, but he was not able to drive them out of the country. In 886 , he had to reach the agreement with the Vikings, which allowed them to live in the northeast part of England. After that, the Danes settled down peacefully. They were assimilated to the English culture and converted to the Christian religion.

The Danes brought into the English language a large number of Danish words, many of which became part of the everyday English vocabulary. The British system of counting by the unit of 12 was also adopted from the Danes: a dozen means 12; 12 pennies made up one shilling of the old English money; one foot has 12 inches. English has the idiom six of one and half a dozen of the other.

2.2.4 The Norman Conquest The Normans were also from the Scandinavian countries. They invaded France in the 9th century. They were converted to Christianity and adopted the French language. In 1066, English king Edward died without an heir. William, Duke of Normandy and cousin of Edward, believed that he should be the king of England. William was very angry and invaded England when Harold was made king of England. On Christmas Day, 1066, William was crowned king of England in Westminster Abbey. Norman control was soon established throughout the country.

French culture became the dominant culture in England because the Norman nobles dominated the English society. As a result French replaced English as the official language. English has a large French vocabulary or idioms connected with French. For example, if a visitor leaves without saying good-bye to the host, English will say he takes French leave. It's said that the etiquette was popular in France in the 17th century. Idioms such as "take heart, stew in one's own juice, return to one's muttons" are literal translation from French.

2.3 Reflecting Religious Belief Religion has played an important role in all peoples' historical development. The Christian culture has ruled Europe for nearly two thousand years. Britain has been a Christian country ever since St. Augustus and his monks converted the English to Christianity in the 7th century. They believe in God and the Bible, though their forms of worship and interpretation of the Bible vary now. The Bible is a book of required reading for them, from which many famous sentences have already become their mottoes about the philosophy of life. English idioms are deeply influenced by the Bible.

This idiom "beard the lion" derives from the Bible: the Old Testament (1 Samuel, 17:34-35). Later, Scottish poet Walter Scott quoted the idiom and added 'in his den' in his poem. "And dar'st thou/Beard the lion in his den...?" Now this idiom means "defy somebody in his own stronghold".

2.4 Reflecting Geographical Background (Natural Environment) Natural environment is the essential condition for existence to man, so different living surroundings may exert different influences on the culture of a nation. Geographically, Britain is an island country surrounded by water on all sides. Sea transportation occupies a special position in Britain's transportation. Undoubtedly, there is no modern Britain without navigation. English people's life is closely linked with sea. People created a lot of idioms that connect with water, sea or navigation: go to sea, put out to sea, feel under the water, etc.

Dense rivers and long coastlines around the British Isles make Britain reserve rich fishery resources. 
Fishing plays a highly important role in British economy especially before the Industrial Revolution. Many idioms come from fishery: have other fish to fry, make fish of one and flesh of another, a fine kettle of fish, cry stinking fish.

Britain is also an island country with unitary maritime climate. Temperature between winter and summer varies slightly due to the North Atlantic Drift which is a continuation of a warm current. It flows past Britain and various rivers carry the warm water inland. This makes the climate warmer in the winter and cooler in the summer. The rainfall is also on the average because winds blowing off the Atlantic Ocean bring clouds and large amounts of moisture to the British Isles. Therefore, English has idiom like "as right as rain", "come rain or shine", "not have sense to come in from the rain".

Britain is not only abundant in rain but also rich in fog especially in winter. London enjoys the fame of "foggy capital", which has 50 foggy days per year on the average. It is difficult for persons to walk in the fog because they cannot see the distance beyond three feet steps. Sometimes they find they are lost in the way. English has such idioms as in a fog, have not the foggiest (idea).

Coal mining can be traced back to 13th century and played an important role in the Industrial Revolution. Nowadays the peak of coal mining is gone, but idioms derived from coal mining remain. Newcastle is a famous coalfield and the earliest coal export port in the world. If he carries coals to Newcastle, he makes unnecessary move. Later, people use the idiom carry coals to Newcastle to describe vain labor with no profit. Another idiom connected with Newcastle is as common as coals from Newcastle. It means very common.

2.5 Reflecting Customs and Habits Social customs vary in different countries and get involved in every field of social life. Customs are affected by economy, politics, religion, literary, and vice versa. Language as a special part of nation culture surely reflects social customs of a nation. Idioms are closely related with national customs.

Eating and drinking habits are inevitably connected with the environment and customs of a nation. Bread, butter and jam are staple food for English people. Many idioms come from them, e.g: know which side one's bread is buttered, as different as chalk from cheese, have jam on it.

Tea is British traditional drink, as bread is their staple food. They can drink tea at any time of a day, especially they like drinking afternoon tea at four or five o'clock every day. Many idioms come from it: a storm in a teacup, high tea, low tea.

Milk, pie and pudding are also favorite drink and food for British people. The British created such idioms as no use crying over spilt milk, live on wind pudding, as easy as pie, pie in the sky, have a finger in every pie, etc.

2.6 Reflecting Sports \& Entertainment British invented cricket, soccer, rugby, tennis, squash, badminton and snooker. In addition, they have made the first rules for such sports as golf, hockey and boxing. Sports thus occupy an important position in British lives. People of all ages participate in all kinds of sports. Idiom as a mirror of culture will naturally reflect them.

Horse Racing was regarded sport of kings in the past. Later it becomes a common and popular spectator sport. British people seem to take a special fancy to racing. Many idioms are from Horse Racing such as win in a canter, win hands down, get into one's stride, straight from the horse's mouth, in the long run, neck and neck.

Boxing originated from ancient Greek and was popular in England in the early 18th century. In 1719 James Figg started the first Boxing Arena in London. Many idioms come from boxing: out for the count, below the belt, pull one's punches, etc.

Cricket is Britain's national sport, which was played as early as 250 years ago. The popularity of cricket finds expression in the English language. If the British think something important, they will say "as significant as a game of cricket". When they say, "that's no cricket", they mean "that's not fair", and contrarily, "to play cricket" means "to be fair".

Entertainment forms an important part of the popular culture. The British people have various forms of entertainment, but one of the most popular places where people entertain themselves is the public house, commonly known as pub. It is in general a place where alcoholic beverages, especially beer, are sold and consumed. The pub also serves as a kind of center of community life, 
where information of all kinds is exchanged and games like darts, billiards are played. Many idioms come from pub culture: small beer, cry in one's beer, on the beer, chalk it up.

2.7 Reflecting Mythologies \& Fables Mythology embodies striking national characteristics and provides soil for the development of national culture. Language's influence also permeates through mythologies and fables. Idioms are not exceptional.

Kill the goose that lays the golden eggs

A farmer and his wife once had a goose that laid golden egg every day. One day the farmer's wife said to her husband, "These eggs are very well, my dear, but though I suppose we will be rich in the end, it is a very slow way of making a fortune. By the time we get it, it will not be worth half what it is today. Now I have an idea. It is obvious that there must be great store of golden eggs inside our goose. Why should we wait all lives for her to lay them? Go and get the knife and we'll have all the gold now while we can still enjoy it." Without any words the farmer killed the goose and cut it open - only to find that inside it was just like any other goose, with no sign of a golden egg at all. Later "kill the goose that lays the golden eggs" is used to describe greedy deeds.

\subsection{Reflecting Literary Works}

Shakespeare is one of the greatest writers the western world has ever produced. He is a master of the English language, with a large vocabulary of 16000 English words. A lot of words, phrases, or names of characters in his works became popular idioms, which are used widely in everyday life until now. For instance, paint the lily originated from King John (Act IV, Scene II):

To gild refined gold,

To paint the lily,

\section{Conclusion}

English teems with idioms. Idiom is a mirror of culture and clearly reflects cultural characteristics of a nation. Sometimes it is rather hard for language learners who do not belong to the source culture to understand idioms, let alone the appreciation of them. So it is significant to learn idiom's cultural connotation such as geography, history, religion, customs, sports \&entertainments, fables \& mythologies, literary works, etc. because they are parts of subcultures.

\section{References}

[1] E.A. Nida, Language and culture, Shanghai: Shanghai Foreign Language Education Press. pp.139, 2001.

[2] C. Fernando, Idioms and Idiomaticity, London: Oxford University Press, 1996.

[3] Y.C. Deng, R.Q. Liu, Language and Culture, Beijing: Foreign Language Teaching and Press Press, pp.3, 1989.

[4] R. Moon, Fixed Expressions \&Idioms in English: A Corpus-Based Approach, Oxford: Clarendon Press. 1998. 